- hogy a térbeliség átélése és a regionális aránytalanságok masszívan összefüggenek;

- hogy az állami szerepvállalást csakis az legitimálhatja, ha közvetetté válik és célja a helyi, regionális erôforrások bekapcsolása a fejlesztések finanszírozásába;

- hogy a területi politika irányítási-hatalmi aktusaiban nagyobb szerepet kell kapnia a szociális kompenzációknak és a felzárkóztatás tudatos stratégiájának, valamint a helyi kormányzati szerep önállósági szintje növelésének, továbbá nemcsak a sikerszférákat kellene privatizálni, hanem az államosított területi funkciók egyre nagyobb részét is társadalmasítani szükséges.

A területi érdekek, a térbeli szerepek átélése és reprezentálódása, valamint a területi egyenlôtlenségek (legalább minimális mértékűre) csökkentése egyelôre esêlytelennek látszik nálunk. $\mathrm{Az}$ a törekvés azonban, hogy a hozott történelmi hátrányokat, különbségeket, aránytalanságokat és kontinuus kilátástalanságokat csökkenteni kellene, csak egy valóban demokratikus, a maga erōforrásainak egészséges fölhasználására vállalkozni képes társadalomban valósulhat meg. Ahhoz azonban hogy ilyen társadalom egyáltalán kialakulhasson, a társadalmi és területi egyenlótlenségek mérséklése szükséges, amelyet e problémák belátásának, fölismerésének kell elengedhetetlenül megelõznie. Ehhez járul hozzá az Enyedi György szerkesztette új kötet kutatógárdája, mintegy máris csökkentve azt a hátrányos helyzetet, amelybe a tértudományok nem ismeröinek többsége szorult, $\$$ ahonnan legalább a tudás-színũ egyenlőségek felé számos lépést tehet e kötet révén.

A. Gergely András

\title{
MÓRAHALOM: A TELEPÜLÉS FÖLDJE ÉS NÉPE
}

\author{
Juhász Antal (szerk.) 1992 \\ Mórahalom Város Önkormányzata, 588 o.
}

Szeged városa 1892-ben a mai Mórahalom helyén Alsóközpont néven tanyai közigazgatási központot létesített, amely lassan faluvá cseperedett és a hatalmas kiterjedésû Alsótanya nagyobbik felének tényleges központjává vált. A tanyaközpontként indult települést és 14624 katasztrális holdas területét 1950. január 1-jén kihasították Szeged határából. Mórahalom néven önálló község alakult, amely jelentôs növekedés és fejlốdés után 1970. jan 1-jén nagyközségi, 1989-ben pedig városi rangot kapott. Alig száz év alatt tehát, folyamatos belsõ fejlôdéssel város nôtt a homokon, város a hajdanán csak egyszerüen VÁROS-ként tisztelt Szeged határá- 
ban. Ha a településeknek lenne karriertörténete, Mórahalom bizonyára pályázhatna a pálmára.

A száz éves születésnapot Mórahalom úgy ünnepelte, hogy tudós kutatókkal könyvet íratott. Az eredmény nem volt kétséges, amikor 1989-ben a kutatócsoport megszervezését, vezetését és a kötet szerkesztését - az efféle munkákban nagy tapasztalattal rendelkező - Juhász Antalra bízta. Az impozáns könyv rekordiđố alatt elkészült, $s$ haszonnal szolgálja a mǒrahalmiak önismeretét és a magyar tudományt egyaránt.

Jó példák lebeghettek Mórahalom vezetốinek szeme elốtt, amikor elhatározták, hogy könyvet íratnak pátriájukról. Szeged környéke ugyanis bôvelkedik viszonylag új, alapos helyismereti monográfiákban. A legfontosabbak: Tápé története és néprajza (szerk. Juhász A. Tápé, 1971); Tanulmányok Kistelek történetébôl és népéletébôl (szerk. Juhász A. Kistelek, 1976); Szöreg és népe (szerk. Hegyi A. Szeged, 1977); Sándorfalva története és népélete (szerk. id. Juhász A. Sándorfalva, 1978); Deszk története és néprajza (szerk. Hegyi A. Szeged-Deszk, 1984) ; Algyõ és népe (szerk. Hegyi A.Szeged, 1987).

Ha végigtekintünk a helységneveken, láthatjuk, hogy a monográfiákkal bemutatott falvak ezer szállal kötôdnek ugyan Szegedhez, de történeti értelemben mégsem szegedinek, hanem Szeged-környéki önálló településeknek mondhatók. A mórahalmi monográfia az elsô, amely a történeti Szeged egyik hajdani határrészének múltjáról és népéletéröl ad képet. Ez a tény felveti azt a kérdéskört: vajon lehet-e és miként lehet a részrốl szólni az egész nélkül? Érdemes-e a részrôl szólni, ha az egészrõl már sokan és sokat szóltak? Egészen pontosan arról van szó, hogy Szeged kiváló történelmi és néprajzi irodalmat mondhat magáénak, mely képet ad a történelmi Szeged határának történetérôl és a szegedi nép hajdani életérốl, de a nagy egész ábrázolása mellett sok részletre nem térhet ki. A mórahalmi monográfia bebizonyította, hogy a nagy egészen belül a rész alapos megismertetésének van létjogosultsága. Azon kívül, hogy Mórahalomnak van néhány évtizedes ,kkülön utas" saját történelme is, a szegedi história nagy egészén belül is megvannak a jellegzetes alsótanyai terület agrártörténeti, településtörténeti és mũvelôdéstörténeti sajátosságai. A néprajz pedig új kutatási módszerek alkalmazásával, a klasszikusnak mondott néprajzi kép után következô változó idốk képének felvázolásával, valamint különleges részletkérdések vizsgálatával tud újat mondani a hajdani szegedi határ egy részére és a szegedi népesség, a ,,szögedi nemzet" egy csoportjára vonatkoztatva.

A kötet elején Csizmazia György, Csongor Gyózó és Kovács Sándor Tibor bemutatja a mórahalmi határ természeti földrajzát, növény- és állatvilágát; Scheffer Krisztina felsorolja az Alsótanyáról származó régészeti leleteket és közli Móra Ferenc egyik hajdani ásatási beszámolóját.

Mórahalom a szegedi tanyavilág egyik széles szeletébôl szervezổdött önálló községgé, ezért a kötet fölöttébb figyelemreméltó fejezete Juhász Antalnak ,,A tanyák településtörténete" címũ írása. A szerzõ 
az elmúlt három évtizedben kiváló tanulmányokat írt a szegedi tanyák múltjáról. Többek között 1975-ben egy etnográfiai összefoglaló tanulmányt tett közzé a szegedi tanyafejlődésrôl, 1989-ben, pedig önálló könyvet publikált a szegedi táj tanyáiról, miután elegáns könnyedséggel írhatta meg a mórahalmi tanyák históriáját.

Az elôzmények ellenére szakmai szempontból fontos a mórahalmi tanya-tanulmány elkészülte. Az elóbb jelzett mũvek ugyanis összefoglaló írások voltak, amelyekben a feltárt adatoknak csak egy töredéke kerülhetett napvilágra. A mórahalmi tanulmány megírásakor a szerzônek lehetôsége nyílt arra, hogy a Mórahalom területére vonatkozóan feltárt, de eddigi összefoglaló munkáiban kényszerũen mellôzött adatait közreadja. Ez mindenképpen nyeresége a magyar néprajztudománynak.

A tanulmány mintaszerũ alapossággal megírt dolgozat. Nagy erénye, hogy a tanyatörténeti tanulmányok többségével ellentétben eljut a máig. Tanulságosan elemzi a tanyapusztulás és a tanyák továbbélésének politika szabdalta vonulatait.

G. Tóth Magdolna az önálló községgé alakulás elốtti fél évszázad történetének, Belényi Gyula a községgé alakulás eseményeinek állít emléket. Szabó Vilmos a hatalmas tanyavilág és a fiatal belterület földrajzi neveit gyũjtötte csokorba.

Juhász Antal a történeti tanulmányok közé illesztette a ,,Társadalmi tagolódás a 20. század elsô felében" címũ írását, melyben - módszerét tekintve - jobbára dominál a néprajzi elem. E körülmény sokat használt a tanulmánynak, mivel megkímélte a helytörténeti monográfiák társadalomtörténeti elemzéseinek szokásos egyhangúságától és unalmától.

A község 1944 és 1970 közti történetét Kanyó Ferenc és Belényi Gyula mutatják be. Hozzájuk kapcsolódik Horváth Dezsó írása a mũvelôdés intézményeirõl.

Különös színfoltja a kötetnek Duró Annamária kiváló és tanulságos társadalomföldrajzi elemzése a mórahalmi tanyavilág jelenérôl és jövôjének lehetséges útjairól.

A kötet több mint egyharmadát adatgazdag néprajzi tanulmányok teszik ki: Bárkányi Ildikó értekezése a régi gyermekéletrõl; Juhász Antal elemzése a tanyatelekrõl, a házról és berendezésérốl; Fodor Ferenc leírása a tanyai gazdálkodásról; Nagy Vera módszertanilag is újszerũ közleménye a termelt javak feldolgozásáról és értékesítésérõl; Fejér Gábor cikke az iparosokról és a kézmũves specialistákról; ifj. Lele József írása a szokásokról és a vallásos népéletrôl, valamint Ónozó Lajos mórahalmi gyữjtésũ népdalközlése.

A könyvet néhány dokumentum szövege és Tanács István ,Fordulópont" címũ cikke zárja. Az utóbbi képet ad a rendszerváltásról, közben vissza-visszatekint az 1960-as, 70-es és 80-as évek mórahalmi történéseire.

A kötet borítóját a mai Mórahalom területén született, de korán Miskére költözött Tóth Menyhért festôművész „Parasztok” címû képének reprodukciója díszíti.

Bárth János 